\title{
TECHNICAL ASSESSMENT OF UBC PILOT PLANT USING COMPUTER PROCESS SIMULATION
}

\author{
Muhammad Hanif, Dhani Avianto Sugeng and Johan Cruyff \\ Energy Resources Development Technology Centre \\ The Agency for Assessment \& Application of Technology (BPPT) \\ E-mail: hanive@hotmail.com
}

\begin{abstract}
Indonesia memiliki sumber daya batubara peringkat rendah dalam jumlah yang berlimpah ( \pm 38 juta ton).Jenis batubara tersebut belum sepenuhnya dikaji meskipun diketahui memiliki berbagai kelebihan seperti kadar abu dan sulphur rendah. Teknologi UBC didedikasikan untuk memproduksi batubara yang dengan nilai jual yang tinggi dan mampu meningkatkan pemanfaatan batubara peringkat rendah di Indonesia. Tulisan ini membahas evaluasi proses Upgraded Brown Coal (UBC) dengan menggunakan data pengoperasian pilot plant UBC di Palimanan. Lingkup kegiatan ini juga merupakan lingkup tanggungjawab BPPT dalam kerjasaa Jepang dengan Indonesia di bidang pengembangan teknologi $U B C$.
\end{abstract}

Keywords: batubara peringkat rendah, upgraded brown coal (UBC), pilot plant

\section{INTRODUCTION}

Coal plays an important role in the world's energy system and thus global economic and social development. In Indonesia, low rank coals have been considered as a potential energy source due to their low costs and huge deposit. Therefore, in securing a smooth transition to greater coal utilizations, Indonesia would require strategic policy, consideration and clear measures to meet the challenges.

The biggest part of the coal deposit in Indonesia is low rank (about $67 \%$ are lignite and low grade sub-bituminous), and this part of reserves is still poorly utilized. The problem faced with this kind of coal is mostly due to its inferior properties such as low heat value (3000-5000 $\mathrm{kcal} / \mathrm{kg})$, high moisture content $(30-50 \%)$ and high tendency for spontaneous combustion. These coals becomes less apt to be transported or to be used directly. However, due to the low ash and sulfur content they become potential to be utilized as clean coal. And moreover, they are mostly deposited close to the surface, so the production cost is very low.

Because of the high moisture content of brown coal, dewatering or drying is needed to be able to upgrade utilize it technically and economically Often overlooked or underestimated, the cost of evaporating $60-70 \%$ of the coal bulk mass conforms as the major barrier to the economical development of commercial utilization. This has led to a search for a proper drying process.
The UBC process is designed to produce a stable and high-calorific fuel and is based on coal-slurry dewatering technology, which is developed by Kobe Steel, Japan. A pilot plant of 5 tons/day (raw coal base) has been erected and operated in Palimanan, Cirebon, West Java, Indonesia. Its goals are to investigate the process performance and to obtain engineering data for scaling up needs.

Technically, energy consumption and operating conditions have big influence to the cost of coal upgrading process. The cost will rise if energy consumption and the operating temperature/pressure are higher and vice versa.

The UBC technology is basically a water removal process that has been developed to avoid the disadvantages of the conventional evaporative process.

Conceptually, water in the coal will be effectively evaporated if led through a conventional shell and tubes heat exchangers in the form of slurry with high heat transfer coefficient. The energy for evaporation of water is huge, but energy consumption could be saved remarkably by using mechanical vapor recompression. Energy saved by recovering the latent heat of the separated moisture at mild operation condition will result in minimum pollutant content of the waste water, since no thermal decomposition of coal occurs. Light oil is used for slurry making with coal together with a small fraction of heavy oil. 
This paper addresses the process evaluation efforts on the upgrading of Indonesian low rank coal using Upgraded Brown Coal (UBC) process. The emphasis is on the demonstration of computer simulation for a 5 TPD UBC process pilot plant.

\section{PROCESS DESCRIPTION}

A conceptual process flow diagram of the UBC process is illustrated in Figure 1. The UBC pilot plant processes 5 tones a day low rank coal and consists of process units, utility and control room.

Pulverized coal and heavy oil fraction (asphalt) are mixed with light oil fraction derived from petroleum (kerosene) at temperature of 60 to $80^{\circ} \mathrm{C}$. The oil to coal ratio in the slurry is approximately 1.2 to 1.5 . The slurry is introduced into a pre-heater via a pump and is heated up to the boiling point of water under the operating pressure. Then, the heated slurry is sent to the tube side of the evaporator. By means of flashing, the water contained in the coal is evaporated and separated from the slurry. The separated vapor is re-compressed and supplied to the shell side of the evaporator to supply heat to the water in newly supplied slurry. More than $90 \%$ of the moisture content is expected to be removed here. The typical operating condition is $140^{\circ} \mathrm{C}$ and $350 \mathrm{KPa}$.
As dewatering proceeds in the evaporator, asphalt is preferentially adsorbed onto the inner surface of coal pores. As the light oil fraction is recovered, the adsorptive asphalt remains there to disable active point in the pores and prevent water to slip back in. Therefore, the product (UBC) has fewer tendencies to spontaneous combustion and water re-absorption.

In order to recover the light oil economically, a two-step oil recovery system is adopted. In the first step, dewatered slurry is sent to the coal-oil separation section, and the light oil is roughly separated from the slurry by mechanical method for example a centrifuge or a screw decanter or a thermal flash separator. Whereas in the final step a small amount of the light oil still remaining in the pores of coal is recovered by a conventional drying system for example a steam tube dryer, or a fluidized bed dryer. Finally $99 \%$ on the light oil is expected to be recovered. Hence, the remaining light oil content of the UBC product can be reduced to less than a few percent.

The UBC product is powder like, so that agglomeration of the product is necessary for its transportation if the user site is located away from UBC factory. Due to its rich oxygen content binder-less briquetting can be applied.

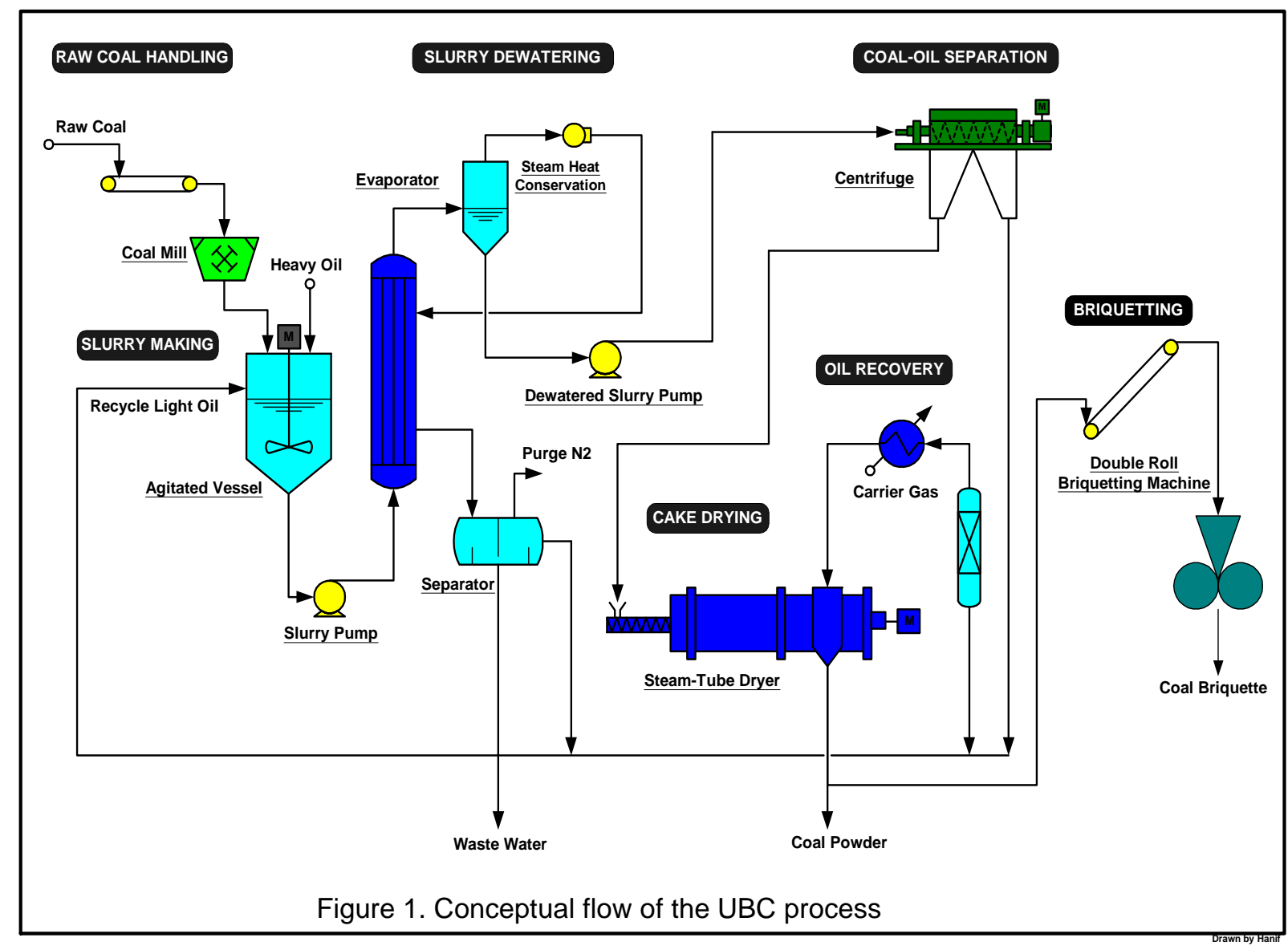




\section{METHODOLOGY}

In this study, a generic computer model was set up to suit the application of coal technology. Physical and thermo-dynamical properties of the coal used are estimated from the scarce sources. The model used is still under development to obtain validity and reproducibility, to be able, in turn, to facilitate the technical assessment of UBC process. This model simulates the steady state conditions of the slurry making process (SECTION 200), oil recovery (SECTION 300) and drying (SECTION 400).

The UBC process runs on a semi continuous basis, that is only the drying process works continuously. To be able to be compared with the steady state simulation conditions, the averages of the mass and heat flow from the operation data is taken into account.

Finally, the model is tested by comparing the calculation results with the design basis, whereupon the process model is extrapolated.

\section{DESIGN BASIS}

This study was carried out on the basis of data collected in the pilot plant from running operation $7^{\text {th }}$ and $11^{\text {th }}$, as summarized in Table 1.

Table 1. Design basis

\begin{tabular}{|lll|}
\hline Items & Run $7^{\text {th }}$ & Run $11^{\text {th }}$ \\
\hline Coal Source & Kidec & Kideco \\
Total operation period & $71.9 \mathrm{hrs}$ & $78 \mathrm{hrs}$ \\
Total coal processed & 5.9 tons & 6.0 tons \\
Operability & on d.b. & on d.b. \\
& $50 \%$ to & $50 \%$ to \\
Coal conc. recycle oil & $75 \%$ of & $100 \%$ of \\
Briquette produced & design & design \\
DewateringConditions & cap. & cap. \\
Pressure & $20 \mathrm{~g} / \mathrm{L}$ & $25 \mathrm{~g} / \mathrm{L}$ \\
Temperature & $5 \mathrm{ton}$ & 5 tons \\
& & \\
& $0.2-0.3$ & $0.3 \mathrm{MPa}$ \\
& $\mathrm{MPa}$ & $160{ }^{\circ} \mathrm{C}$ \\
& $155-$ & \\
& $160^{\circ} \mathrm{C}$ & \\
\hline
\end{tabular}

\subsection{Feedstock Characteristics}

Feedstock characteristic of coal and heavy oil used for the process simulations are given in Table 2 and Table 3 . In the runs mentioned Kideco coal from East Kalimantan is used, while heavy oil (LSWR) analysis is obtained from Pertamina, Cilacap.

Those figure were selected in order to satisfy the requirement for self-consistent chemical analysis and heat content data solely for use in the process simulations. Although it is recognized that a broad range of coal quality and coal-oil ratio parameter could influence the design of system, this study focused on moisture content and specific energy parameters.

Table 2. The coal analyses results used for the calculations

\begin{tabular}{|ll|}
\hline Properties & $\begin{array}{l}\text { Coal } \\
\text { Sample } \\
\text {-Kideco }\end{array}$ \\
\hline Total Moisture (\%wt raw coal a.r.) & 38,4 \\
Specific Energy (kkal/kg) & \\
Gross as received basis & 4020 \\
Gross as air dry basis & 5090 \\
Proximate Analysis (wt\% dry basis) & \\
Ash & 2,9 \\
Volatile Matter & 48,9 \\
Fixed Carbon & 48,2 \\
Elemen Analysis (wt\% daf) & \\
Carbon & 68,53 \\
Hydrogen & 5,09 \\
Nitrogen & 1,22 \\
Sulfur & 0,15 \\
Oxygen (by diff.) & 25,01 \\
& \\
\hline
\end{tabular}

Table 3. Properties of heavy oil (low sulfur wax residue)

\begin{tabular}{|ll|}
\hline Properties & Result \\
\hline Ash Content (wt\%) & 0,008 \\
Conradson Carbon Residue (wt\%) & 3,8 \\
Density $15^{\circ} \mathrm{C}$ & 910,7 \\
Flash Point ( $\left.{ }^{\circ} \mathrm{F}\right)$ & 194 \\
Pour Point $\left({ }^{\circ} \mathrm{F}\right)$ & 115. \\
Total sulfur (wt\%) & 0,20 \\
Specific Gravity $\left(60 / 60^{\circ} \mathrm{F}\right)$ & 0,9112 \\
Visco Redwood at $140^{\circ} \mathrm{F}(\mathrm{Sec})$ & 164 \\
Water content (vol \%) & 0,1 \\
\hline
\end{tabular}

\subsection{Thermo-Physical Properties}

Materials such as coal, light and heavy oil are defined as discrete components in the model. A library containing physical and thermo-dynamical properties of coal is constructed to provide baselines for the calculations.

Properties are estimated from average molecular weight, specific gravity and/or normal boiling point using API oriented methods. Other estimated properties are molecular weight, critical temperature, critical pressure, critical volume, acentric factor, liquid volume constant, ideal gas heat capacity coefficients for the polynomial equation, solubility parameter and the Watson factor. 


\subsection{Modelling The Process Flow}

By careful selection and linking of various modules, it is possible to build up an overall model of the process flow. Executing the model provides complete heat and mass balance at equilibrium under steady state conditions.

The calculation results are expressed in terms of heat and mass flow, for the stream passing between the various modules. The calculation sequence normally follows the logical order in which the modules have been defined through the flow sheet. These can be used to optimize the calculation process by minimizing the number of variables for which preliminary estimates are necessary in order to start the calculation sequence. The scheme chosen for investigation are shown in Figure 2. This scheme was adopted from the pilot plant flow sheet. The design basis parameters and assumptions for system are set out in Table 5 in the attachment 1.

\subsection{Thermodynamics Model}

In addition to the calculations of temperatures, pressures, enthalpies and entropies, thermodynamic routines are employed to predict the vapor/liquid behavior of process stream. Thermodynamics model used in this study are Ideal Vapor Pressure (water/hydrocarbon immiscible) for K-Value and Latent Heat for enthalpy model. Using the sensitivity analyses as well as optimization, this system provides an efficient method to study a process.

\section{SIMULATION RESULT AND DISCUSSION}

Figure 3 shows the UBC qualitative diagram that is divided into 3 primary sections, i.e. slurry dewatering, coal-oil separation and oil recovery.

The qualitative diagram labels all significant streams in the process flow. All pieces of equipment are labeled according to location. Code letters describe each type of equipment. The streams are described in detail in Table 6
(Material Balance). Listed are summary of the composition, temperature, pressure, and stream properties

\section{CONCLUSION}

KIDECO coal surprisingly fit the model easily during its first calculation runs. However, the validity of the model will still have to be examined by feeding more operation data.

Basic properties of Indonesian low rank coal are still scarcely studied. To prevent to many estimations in the calculations a thorough research on this issue will prove to be very useful.

BPPT aims this model to be developed further by acquiring more operation data. These are mandatory to extrapolate the model behavior more accurately.

\section{REFERENCES}

Maude, C., 1993. Advanced power generation a comparative studio of design option for coal, IEA coal Research, London.

Hehlmann, J., Computer simulation in CHEMCAD ${ }^{T M}$ coal drying process, Instytut Chemicznej Przeóbki Węgla, Zabrze.

J.A, David., C.Y, Young., Utilisation of Low Rank Coals, Envirosafe International Pty Ltd 1a Yarrbat Avenue, Balwyn, Vic 3133, Australia.

Low-Rank Coal Upgrading Technology (UBC Process), Japan Coal Energy Centre; the Institute of Applied Energy; Kobe Steel, Ltd; Nissho Iwai Corp. 
Table 5. Design basis parameters and assumptions for the system

\begin{tabular}{|c|c|}
\hline Items & Value \\
\hline \multicolumn{2}{|l|}{ Coal } \\
\hline Type & Lignite \\
\hline Coal Feed $[\mathrm{kg} / \mathrm{h}]$ & 200 \\
\hline Coal-Oil ratio & 1.75 \\
\hline \multicolumn{2}{|l|}{ Ambient conditions } \\
\hline Pressure, bar & 1 \\
\hline Temperature, deg.C & 25 \\
\hline Air humidity,\% & 70 \\
\hline \multicolumn{2}{|l|}{ Steam condition } \\
\hline \multicolumn{2}{|l|}{ Pressure, bar } \\
\hline \multicolumn{2}{|l|}{ Module size } \\
\hline Number of vessel & 6 \\
\hline Number of pump & 6 \\
\hline Number of $\mathrm{HE}$ & 4 \\
\hline Number of Centrifugal & 1 \\
\hline Number of crusher & 1 \\
\hline Number of Dryer & 1 \\
\hline Number of Controller & 3 \\
\hline Pump efficiency, $\%$ & 75 \\
\hline \multicolumn{2}{|l|}{ Raw Coal Handling } \\
\hline Major equipment & Hammer Mill Crusher \\
\hline Bond work index & 11.37 \\
\hline Particle size, $\mathrm{mm}$ & 3 \\
\hline \multicolumn{2}{|c|}{ Slurry Making and Dewatering } \\
\hline Major equipment & $S \& T$ Heat Exchanger \\
\hline Temperature, deg. C & 150 \\
\hline Pressure, $\mathrm{kPa}$ & 0.4 \\
\hline $\mathrm{U}, \mathrm{kcal} / \mathrm{h}-\mathrm{m}^{2} \mathrm{C}$ & 400 \\
\hline \multicolumn{2}{|l|}{ Coal-Oil Separation } \\
\hline Major equipment & Centrifuge \\
\hline Temperature, deg. C & 120 \\
\hline Pressure, $\mathrm{kPa}$ & 100 \\
\hline Solid loss fraction & 0.044 \\
\hline Speed-RPM & 3000 \\
\hline Moisture fraction & 0.4 \\
\hline Compressibility & 0.075 \\
\hline Specific resistance, $\mathrm{m} / \mathrm{kg}$ & 0.01 \\
\hline \multicolumn{2}{|c|}{ Cake Drying and Oil Recovery } \\
\hline Major equipment & $S \& T$ Heat Exchanger \\
\hline Temperature, deg. C & 175 \\
\hline Pressure, kPa & 100 \\
\hline Moisture fraction & 0.015 \\
\hline Carrier gas, $\mathrm{Nm}^{3} / \mathrm{h}$ & 43.5 \\
\hline Recovered oil slurry, \% & 95 \\
\hline
\end{tabular}




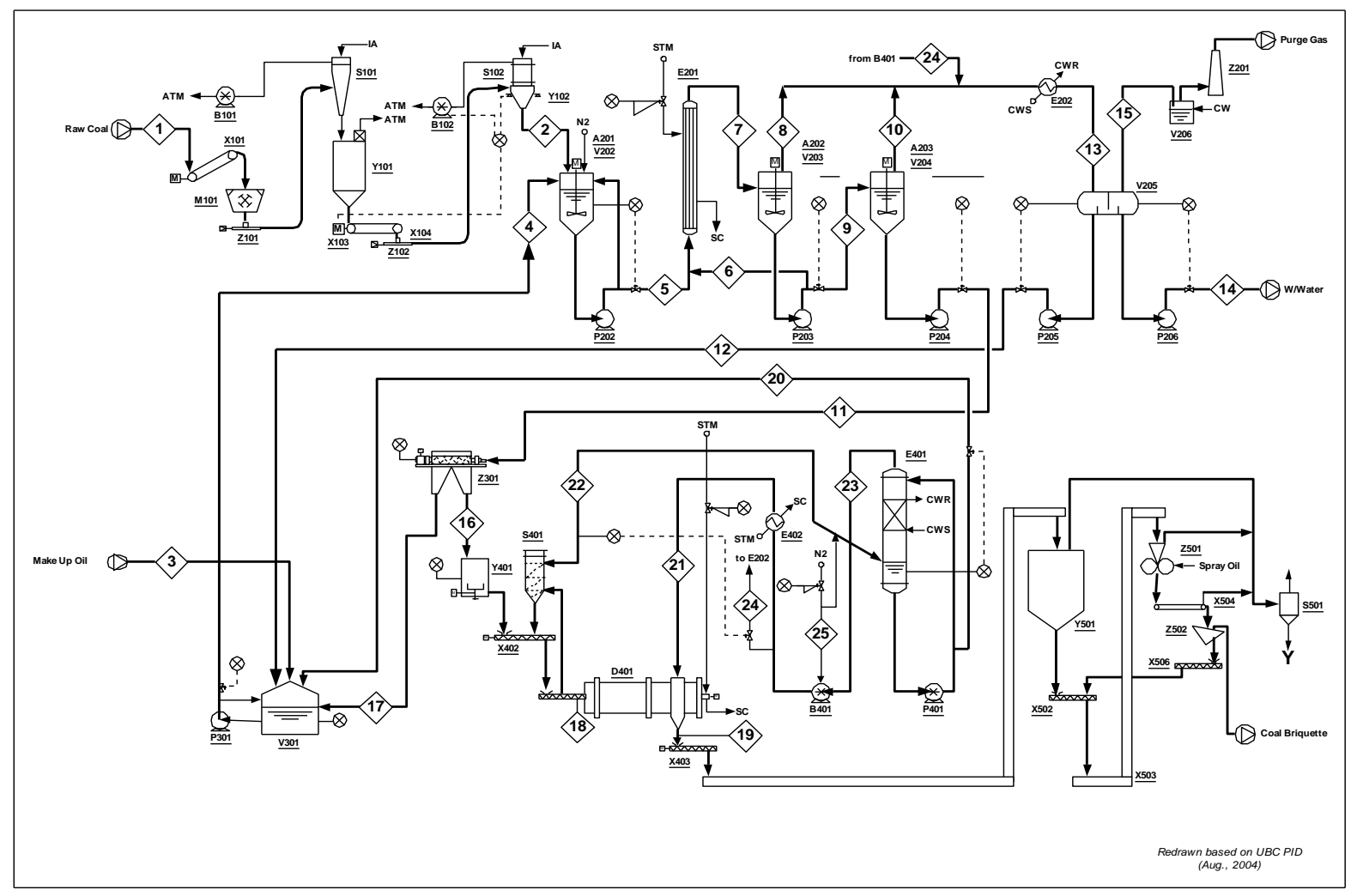

Figure 3. Qualitative Diagram

Table 6. Process Stream

\begin{tabular}{|l|c|c|c|c|c|c|c|c|c|c|}
\hline Stream No. & 1 & 2 & 3 & 4 & 5 & 6 & 7 & 8 & 9 & 10 \\
\hline Fluid & $\begin{array}{c}\text { Coal } \\
\text { Feed }\end{array}$ & Fine coal & $\begin{array}{c}\text { M/U Mix } \\
\text { Oil }\end{array}$ & Feed Oil & $\begin{array}{c}\text { Feed } \\
\text { Slurry }\end{array}$ & $\begin{array}{c}\text { Rec'l } \\
\text { Slurry }\end{array}$ & $\begin{array}{c}\text { Vap.+Slu } \\
\text { rry }\end{array}$ & Vapor & $\begin{array}{c}\text { Dw- } \\
\text { Slurry }\end{array}$ & \begin{tabular}{c} 
Vapor \\
\hline Temp C
\end{tabular} \\
\hline Pres MPa abs. & 0.1 & 0.1 & 0.1 & 0.1 & 0.5 & 0.5 & 0.5 & 0.4 & 0.1 & 0.1 \\
\hline Flowrates in kg/h & & & & & & & & & & \\
\hline D-Coal & 125 & 125 & 0 & 5.81 & 130.81 & 8720.68 & 8720.68 & 0 & 130.81 & 0 \\
\hline Water & 83.3 & 83.3 & 0 & 0.03 & 83.33 & 101.73 & 101.73 & 83.06 & 0.28 & 0.21 \\
\hline L-Oil & 0 & 0 & 0.35 & 180.38 & 180.42 & 5982.18 & 5982.18 & 94.2 & 88.32 & 0.53 \\
\hline H-Oil & 0 & 0 & 1.24 & 1.3 & 1.3 & 86.66 & 86.66 & 0 & 1.3 & 0 \\
\hline Nitrogen & 0 & 0 & 0 & 0 & 8 & 8 & 8 & 8 & 0 & 0 \\
\hline Total kg/h & 208.3 & 208.3 & 1.59 & 187.52 & 403.86 & 14899.3 & 14899.3 & 185.26 & 220.71 & 0.74 \\
\hline Average mol wt & 44.02 & 44.02 & 249.35 & 158.93 & 65.16 & 283.52 & 283.52 & 33.64 & 312.77 & 49.16 \\
\hline Actual dens kg/m3 & 1159.5 & 1159.5 & 699.43 & 721.05 & 206.74 & 346.29 & 294.72 & 3.91 & 230.13 & 1.48 \\
\hline Visc cP & 0.9227 & 0.9227 & 0.8418 & 0.4967 & 0.6531 & 0.2521 & 0.2403 & & 0.2444 & \\
\hline
\end{tabular}


Table 6. Process stream (Continued)

\begin{tabular}{|c|c|c|c|c|c|c|c|c|c|c|}
\hline Stream No. & 11 & 12 & 13 & 14 & 15 & 16 & 17 & 18 & 19 & 20 \\
\hline Fluid & $\begin{array}{c}\text { Dw- } \\
\text { Slurry }\end{array}$ & Rec'l Oil & Vapor & W/Water & $\begin{array}{c}\text { Purge } \\
\text { N2 }\end{array}$ & $\begin{array}{c}\text { Wet } \\
\text { Cake }\end{array}$ & $\begin{array}{c}\text { OF } \\
\text { Slurry }\end{array}$ & $\begin{array}{l}\text { Coal } \\
\text { Cake }\end{array}$ & Dry Coal & $\begin{array}{l}\text { Rec'l } \\
\text { Slurry } \\
\end{array}$ \\
\hline Temp C & 133.21 & 50.26 & 146.57 & 50.02 & 50 & 133.21 & 133.21 & 133.47 & 175 & 80.17 \\
\hline Pres MPa. abs & 0.1 & 0.4 & 0.1 & 0.15 & 0.1 & 0.1 & 0.1 & 0.1 & 0.1 & 0.3 \\
\hline \multicolumn{11}{|l|}{ Flowrates in kg/h } \\
\hline D-Coal & 130.81 & 0 & 0 & 0 & 0 & 125.05 & 5.76 & 125 & 125 & 0.05 \\
\hline Water & 0.07 & 0.03 & 83.34 & 81.54 & 1.76 & 0.07 & 0 & 0.07 & 0 & 0 \\
\hline L-Oil & 87.79 & 95.9 & 96.55 & 0 & 0.65 & 83.91 & 3.88 & 83.12 & 1.87 & 80.25 \\
\hline H-Oil & 1.3 & 0 & 0 & 0 & 0 & 1.24 & 0.06 & 1.24 & 1.24 & $\overline{0}$ \\
\hline Nitrogen & 0 & 0 & 19.58 & 0 & 19.58 & 0 & 0 & 0 & 0 & 0 \\
\hline Total kg/h & 219.97 & 95.93 & 199.47 & 81.54 & 21.99 & 210.28 & 9.69 & 209.42 & 128.12 & 80.31 \\
\hline Actual dens kg/m3 & 933.74 & 724.24 & 0.98 & 987.79 & 1.04 & 933.76 & 933.18 & 935 & 1269.94 & 701.99 \\
\hline Average mol wt & 153.41 & 153.98 & & 18.01 & & 153.41 & 153.41 & 153.41 & 153.41 & 154.33 \\
\hline Visc cP & 0.2786 & 0.6057 & & 0.5645 & & 0.2786 & 0.2786 & 0.278 & 0.2137 & 0.4377 \\
\hline
\end{tabular}

Table 6. Process stream (Continued)

\begin{tabular}{|l|c|c|c|c|c|}
\hline Stream No. & 21 & 22 & 23 & 24 & 25 \\
\hline Fluid & $\begin{array}{c}\text { Carrier } \\
\text { Gas }\end{array}$ & $\begin{array}{c}\text { Rec'l } \\
\text { Gas }\end{array}$ & $\begin{array}{c}\text { Cond. } \\
\text { Out }\end{array}$ & $\begin{array}{c}\text { Purge } \\
\text { Gas }\end{array}$ & N2 Feed \\
\hline Temp C & 175 & 190.17 & 80 & 80.72 & 35 \\
\hline Pres MPa.abs & 0.1 & 0.1 & 0.1 & 0.1 & 0.45 \\
\hline Flowrates in kg/h & & & & & \\
\hline D-Coal & 0 & 1.19 & 0 & 0 & 0 \\
\hline Water & 0.14 & 0.21 & 0.21 & 0.07 & 0 \\
\hline L-Oil & 4.04 & 86.11 & 5.86 & 1.81 & 0 \\
\hline H-Oil & 0 & 0.01 & 0 & 0 & 0 \\
\hline Nitrogen & 25.81 & 25.79 & 37.4 & 11.58 & 11.61 \\
\hline Total kg/h & 30 & 113.31 & 43.46 & 13.46 & 11.61 \\
\hline Actual dens kg/m3 & 0.87 & 2.01 & 1.05 & 1.1 & 4.92 \\
\hline Average mol wt & & & & 154.33 & \\
\hline Visc cP & & & & 0.4333 & \\
\hline
\end{tabular}

